\title{
THE END OF THE HONEYMOON: PENAL DISCOURSE AND THE HUMAN RIGHTS OF PRISONERS IN THE AFTERMATH OF SOUTH AFRICA'S SECOND DEMOCRATIC ELECTION - PART 1
}

\author{
Stephen Allister Peté
}

BA LLB LLM M Phil PhD

Associate Professor of Law, School of Law

Howard College Campus

University of KwaZulu-Natal

Attorney of the High Court of South Africa

\section{SUMMARY}

The years immediately following South Africa's second democratic election, held in June 1999, were significant in that they marked the end of the "honeymoon" period which followed the country's transition from apartheid to democracy in 1994. This article focuses on the public discourse surrounding imprisonment in South Africa during this important "post-honeymoon" period. The article traces the continued systematic violation of the basic human rights of many of those confined in South African prisons throughout the period. Part One of the article deals with the many public debates surrounding chronic prison overcrowding and its effects, whereas Part Two deals with a host of evils which beset the South African penal system at this time, including very poor conditions of detention, high levels of gang activity, the spread of HIV/AIDS, the escape of dangerous criminals from different prisons in the country, and instances of corruption and other criminal activity amongst prisoners and staff.

\section{1 \\ INTRODUCTION}

"The degree of civilization in a society can be judged by entering its prisons."

Fyodor Dostoevsky

South Africa's second democratic election was held on 2 June 1999. It was an important election, in that it served to consolidate the constitutional

\footnotetext{
From Dostoevsky The House of the Dead (1862), translated by Garnett and quoted in Shapiro The Yale Book of Quotations (2006), as reflected in the 2013 IOS Application created and developed by English Channel Inc. Tokyo.
} 
democracy which had been ushered in with the first democratic election held in $1994 .^{2}$ By the time of the second democratic election, the public euphoria which had greeted the demise of apartheid and the dawn of a new democratic era, had begun to dissipate. For the first time since 1994, most South Africans appeared to be pessimistic rather than optimistic about the direction in which the country was headed. ${ }^{3}$ An important factor contributing to the pessimism of many South Africans, as well as constituting a central issue in the election campaign of 1999, was that crime in the country was perceived to be at unacceptably high levels. According to one group of scholars:

"Negative sentiment [towards government efforts to reduce crime] began to mount in late 1996 and skyrocketed in mid-1998. By September 1998, only

$17 \%$ said the Government was doing a good job and a massive $81 \%$ gave it a negative rating. While it recovered slightly as the election neared, crime

(along with jobs) remained one of the ANC's biggest electoral headaches."

In brief terms, therefore, it may be said that, although South Africans remained deeply divided along the lines of race and class, they were united in their fear of crime and the common perception that not enough was being done to combat the problem. ${ }^{5}$ This was to remain a dominant theme within South African public discourse for many years. Moreover, it was a theme which affected the colour and tone of public debate in many other areas of South African life, including the punishment of offenders - which is the focus of this article.

The primary aim of this article is to identify and examine the main themes which characterized the public discourse surrounding imprisonment in South Africa during the years immediately following the country's second democratic election. This article also traces the dialectical relationship between such discourse and the continued systematic violation of the basic human rights of many of those being confined in South African prisons

2 See in general, Lodge Consolidating Democracy: South Africa's Second Popular Election (1999).

3 According to Mattes, Taylor and Africa Public Opinion and Voter Preferences (1999) Chapter 3 1994-1999: "Since 1994, when $76 \%$ of a national sample said the country was headed in the right direction, regular Markinor surveys tracked a gradual decline in optimism about the overall direction of the country, with especially sharp drops after 1996. The first Opinion '99 survey, conducted in September 1998, registered the first time that the optimistic and pessimistic trend lines actually crossed, with $44 \%$ saying the country was headed in the wrong direction, and $43 \%$ saying the right direction." In Reynolds (ed) Election '99 South Africa: from Mandela to Mbeki (1999) 37-63 38.

4 Mattes, Taylor and Africa Public Opinion and Voter Preferences Chapter 3 1994-1999. In Reynolds (ed) Election '99 South Africa: from Mandela to Mbeki (1999) 37-63 44.

5 One consequence of the general atmosphere of fear which was pervasive in South Africa during the early post-apartheid period, given the high levels of violent crime in the country, was the passing into law of minimum-sentence legislation. Minimum-sentencing provisions were passed into South African law in terms of the Criminal Law Amendment Act 105 of 1997 and came into effect on 1 May 1998. Set to expire after a set number of years, the minimum-sentencing provisions were explicitly renewed on a number of occasions, until they were made permanent by $s 3$ of the Criminal Law (Sentencing) Amendment Act 38 of 2007, which removed the need for periodic renewal. This legislation was to have a negative effect on the ongoing problem of prison overcrowding in South Africa. 
during this important period. This was the time during which the inhabitants of Mandela's "rainbow nation" began to realize that the honeymoon of the immediate post-apartheid period was over. South Africans started to appreciate that their new democracy, now under the leadership of Thabo Mbeki, could not easily solve the daunting set of economic and social problems - including deteriorating conditions in the country's prisons - by which it was confronted. South Africans were forced, finally, to accept that the end of apartheid did not mean an end to the abuse of prisoners' basic human rights in poorly maintained and chronically overcrowded prisons, with significant levels of gang activity, and high rates of HIV infection.

This article is divided into two parts:

Part One deals with the public discourse surrounding the important theme of prison overcrowding. ${ }^{6}$ The years leading up to South Africa's second democratic election - the period immediately prior to that examined in this article - was characterized by chronic overcrowding within South African prisons. This gave rise to negative effects which permeated the entire penal system of the country. ${ }^{7}$ Unfortunately, as Part One of this article shows, chronic overcrowding remained a major problem for South African prison authorities during the years following the second democratic election.

Part Two of this article deals with the public discourse surrounding a host of evils which accompanied the chronic overcrowding in South Africa's prisons during the period in question. These evils included poor conditions of detention (particularly distressing in the case of vulnerable classes of prisoners, such as children); high levels of gang activity; the spread of HIV/AIDS; the escape of dangerous criminals from different prisons in the

6 It should be noted that the period examined in this article is not the only period which was characterized by chronic overcrowding within South Africa's prisons. Chronic overcrowding is a prominent theme within South African penal discourse since colonial times to the present. The detailed analysis in Part One of this article of the penal discourse surrounding prison overcrowding in the years immediately following South Africa's second democratic election, forms part of a bigger picture, in which concern over chronic overcrowding plays a prominent part. See, for eg, Peté "Like a Bad Penny: The Problem of Chronic Overcrowding in the Prisons of Colonial Natal 1845 to 1910 - Part 1" 2015 21(1) Fundamina 102-118; Peté "Like a Bad Penny: The Problem of Chronic Overcrowding in the Prisons of Colonial Natal 1845 to 1910 - Part 2" 2015 21(2) Fundamina 341-358; Peté "Holding Up a Mirror to Apartheid South Africa: Public Discourse on the Issue of Overcrowding in South African Prisons 1980 to 1984 - Part 1" 2014 35(3) Obiter 485-505; Peté "Holding Up a Mirror to Apartheid South Africa: Public Discourse on the Issue of Overcrowding in South African Prisons 1980 to 1984 - Part 2" 2015 36(1) Obiter 17-40; Van Zyl Smit "Swimming Against the Tide: Controlling the Size of the Prison Population in the new South Africa" in Dixon and Van der Spuy (eds) Justice Gained? Crime and Crime Control in South Africa's Transition (2004) 227-258; Van Zyl Smit "National Report - South Africa" in Van Zyl Smit and Dünkel (eds) Imprisonment Today and Tomorrow - International Perspectives on Prisoners' Rights and Prison Conditions - Second Edition (2001) 589-608; Peté "The Politics of Imprisonment in the Aftermath of South Africa's First Democratic Election" 19981 South African Journal of Criminal Justice 51-83; Peté "The Good the Bad and the Warehoused The Politics of Imprisonment During the Run-up to South Africa's Second Democratic Election" 2000 13(1) South African Journal of Criminal Justice 1-56; Peté "Between the Devil and the Deep Blue Sea - The Spectre of Crime and Prison Overcrowding in Postapartheid South Africa" 2006 27(3) Obiter 429-453.

See Peté 2000 13(1) South African Journal of Criminal Justice 1-56. 
country; and instances of corruption and other criminal activity amongst prisoners and staff. In addition to the central problem of chronic overcrowding dealt with in Part One, all the above-mentioned evils emerge as strong themes within the public-penal discourse of the time. Each of these themes is closely examined in Part Two of this article.

In order to adequately capture not only the content, but also the "feel" of the public discourse surrounding imprisonment in the aftermath of South Africa's second democratic election, this article makes use of data drawn from a large number of newspaper reports which appeared in a wide variety of South African newspapers during the period in question. Data drawn as well from most major South African daily and weekly newspapers published during this period are reflected in this article. The wide variety of different newspaper reports consulted during the research process produces a vivid picture of this particular time in South Africa's penal history. ${ }^{8}$ In addition to comparing different newspaper reports on particular events, the article also makes reference to official reports and speeches by public officials. While the main focus of this article is on the different strands of public discourse surrounding imprisonment, it also provides an accurate picture of what it was like to be a prisoner in South Africa during the period in question.

\section{THE NIGHTMARE OF CHRONIC OVERCROWDING CONTINUES}

If any theme may be said to dominate the public discourse surrounding imprisonment in South Africa in the aftermath of the country's second democratic election, it is that of continued chronic overcrowding, and its effects. ${ }^{9}$ The issue of prison overcrowding was discussed in the national press from the very beginning of the period in question. In the month following the second democratic election, for example, it was reported that the Minister of Correctional Services, Ben Skosana, and the Minister of Justice, Penuell Maduna, had paid a surprise visit to a number of prisons in the Gauteng area. They found the conditions in the Johannesburg Prison to be shocking. The holding cells were dilapidated, overcrowded and stuffy with no bright lights and with leaking water pipes. A total of 15000 prisoners were detained in the prison, which had been designed to accommodate $6000 .^{10}$

The public pressure brought to bear on prison authorities at this time concerning the issue of prison overcrowding, seemed to cause a degree of overreaction among certain officials. During August 1999, for example, the Commissioner of Correctional Services, Dr Khulekani Sitole, allegedly told Beeld newspaper that, once offenders were sentenced, they forfeited a significant portion of their human rights. According to this report, Sitole

8 There is considerable truth in the following well-known phrase "News is a First Rough-draft of History" 13 June 1948 Washington Post http://www.slate.com/articles/news_and_politics /press_box/2010/08/who_said_it_first.html (accessed 2015-03-07).

9 For a summarized overview of certain of the prominent themes covered in this section, see Peté 2006 27(3) Obiter 438-443.

1025 July 1999 City Press 5. 
maintained that the only rights to which prisoners were entitled, were the rights to food and a place to sleep. He was responding to an allegation by the South African Prisoners Organisation for Human Rights that prisoners were being denied their human rights because 154000 prisoners were being detained in prisons designed to accommodate a maximum of 98000 prisoners. According to the report, Sitole stated that the use of disused mine buildings to accommodate prisoners was being considered. ${ }^{11}$ In response to Sitole's alleged comments, the South African Prisoners Organisation for Human Rights demanded that he be dismissed. ${ }^{12}$

The overcrowded conditions in South African prisons at this time resulted in at least one unfavourable comparison to the conditions prevailing in prisons in other parts of the world. During September 1999, it was reported that a South African serving a term of imprisonment in South America had elected to serve the last six months of his sentence in a Columbian prison, rather than be returned to Pollsmoor Prison in Cape Town. The prisoner, a certain Mr Clive Solomons, maintained that conditions in Pollsmoor Prison were much worse than those in the South American prison - situated in Santa Marta, Columbia - where he was serving a three and a half year sentence. A religious worker who visited Mr Solomons, Shona Allie, stated that, although prisons in South America were a bit overcrowded, the facilities were much better than in South African jails. Most cells were single quarters and married men's wives were allowed to spend weekends with them. She stated that the cells of prisoners in Bogota and Medellin were air-conditioned and that prisoners could walk freely in the prison. ${ }^{13}$

Reports on the harsh realities of life in South Africa's overcrowded prisons did not seem to engender much public sympathy for prisoners. In an editorial which commented on an "open day" which had been held at the Johannesburg Prison, the Pretoria News summed up the general desire of the South African public to see criminals harshly punished, as follows:

“it was with some astonishment that we witnessed a so-called 'open day' at Johannesburg Prison. It was enthusiastically recorded how festive and colourful the day was: soft drinks and cake for prisoners who were treated to plays and games on the prison's sports fields. Rehabilitation is one thing, but what kind of message did this transmit to the public? That prison is in fact not a punishment but a far kinder place than they had imagined? ... The threat of a term in jail - a harsh environment where privileges are few and hard-earned - should serve as a deterrent. The 'open day' conveyed an unfortunate message".

A significant factor contributing to the overcrowding of South Africa's prisons at this time was the large number of awaiting-trial prisoners clogging up the system. Towards the end of 1999, the Minister of Correctional

\footnotetext{
1116 August 1999 Beeld 9. This idea may have been linked to a somewhat bizarre suggestion made more than two years previously - that disused mine shafts be used to accommodate South African prisoners. For a discussion of this suggestion and the public outrage which greeted it, see Peté 2000 13(1) South African Journal of Criminal Justice 21-22.

1218 August 1999 Beeld 2.

136 September 1999 Cape Argus 1.

141 November 1999 Pretoria News 7.
} 
Services, Ben Skosana, expressed concern at the large number of awaitingtrial prisoners within the penal system. He speculated that, by 2002, awaiting-trial prisoners could outnumber convicted prisoners in Gauteng. ${ }^{15}$ At the time he was speaking, awaiting-trial prisoners made up about onethird of the 155000 prisoners in South Africa. Each prisoner cost the South African taxpayer R80 per day, which amounted to R12.4 million per day for the upkeep of South Africa's prison population. The Independent on Saturday described the problem of increasing numbers of awaiting trial prisoners as a "time-bomb", and referred to the overcrowding in South Africa's prisons, which then stood at $156 \%$, as "horrifying". The Minister of Correctional Services attributed the rise in the number of awaiting-trial prisoners to increased police efficiency, and because the courts were too slow in their prosecutions. The Department of Justice, on the other hand, maintained that the increase was due to tough bail laws, which were being strictly applied by the courts. A spokesperson for the Department of Justice, Paul Setsetse, pointed out that the Ministers of Safety and Security, Justice, Defence, and Correctional Services, had recently undertaken a snap tour of South Africa's prisons. They had found that, although most awaiting-trial prisoners had been granted bail, they could not afford to pay and were forced to remain in prison. The Ministers discovered that one awaiting-trial prisoner in Diepkloof had spent 11 months in prison, because he was unable to afford R50 bail. A senior researcher at the Institute for Security Studies, Martin Schonteich, pointed out that, from 1995, the proportion of awaitingtrial prisoners had been increasing in relation to the prison population as a whole. This was due to the tightening of the bail laws, coupled with deterioration in the functioning of the justice system caused by experienced prosecutors leaving the system. According to Schonteich there had been a decrease in the number of awaiting-trial prisoners during the preceding few months, following the establishment of pre-trial service projects by the Government - which assisted magistrates to grant affordable bail. The Minister of Correctional Services indicated that the Government was looking for ways to keep petty offenders out of prison, and stated that: "We need the assistance of non-governmental organizations which can absorb those who commit petty offences, while prisons will deal mainly with hardened criminals". ${ }^{16}$

15 In fact, the massive increase in the number of awaiting-trial prisoners within the South African penal system reached a peak around this time, after which it stabilized and then began to decrease. Unfortunately, this did not bring an end to the problem of overcrowding in South African prisons. Writing in 2006, Muntingh and Gifford commented as follows about prison overcrowding in South Africa during the first decade after the fall of apartheid: "The total number of prisoners has grown steadily and dramatically over the last 11 years. The cause of the increase has changed during this time. Between 1995 and 2000, the major driver of the prison-population rise was a massive increase in the size of the unsentencedprisoner population. After 2000, the number of unsentenced prisoners stabilized, and then began to decrease. But the prisoner population continued to grow, now as a result of an increase in the number of sentenced prisoners." See Giffard and Muntingh "The Effect of Sentencing on the Size of the South African Prison Population - Report 3" 2006 Open Society Foundation for South Africa 2.

164 December 1999 Independent on Saturday 1. 
One of the ways in which the authorities hoped to begin reducing the numbers of awaiting-trial prisoners, was by managing the flow of criminal cases at court. During November 1999, it was announced that the Integrated Management of Awaiting Trial Prisoners Project - which had been running successfully in Durban, Port Elizabeth, Johannesburg, Pietermaritzburg and Empangeni - was being introduced in the Western Cape. The objectives of the plan were to reduce overcrowding caused by awaiting-trial prisoners, by:

1 Reviewing all cases to ensure that there was at least a prima facie case against each awaiting-trial prisoner.

2 Surveying, on a voluntary basis, all awaiting-trial prisoners, in order to determine which of them intended to plead guilty, and then fast-tracking the cases of those who intended to plead guilty.

3 Facilitating the completion of outstanding trials by speeding up the resolution of outstanding issues.

4 Managing corrective action for those cases which were not court-ready, because they still required further investigation. ${ }^{17}$

Another way, in which it was hoped to reduce overcrowding in South African prisons, was to introduce a system of electronic monitoring of prisoners. During November 1999, the Minister of Correctional Services stated in Parliament that such a system would be implemented during the 2000/2001 financial year - with R83.65 million set aside in the medium-term expenditure framework for this purpose. As at 30 September 1999, the capacity of the 236 prisons in South Africa was 99803 prisoners, whereas the total prison population amounted to 157575 prisoners. ${ }^{18}$

Despite the initiatives to reduce overcrowding, the situation in many prisons remained grave. Towards the end of 1999, the Boksburg Prison came under the public spotlight after the head of the prison, Benjamin Modisadife, told the Sunday Independent that the prison had been operating in "crisis-management mode" for a number of years due to overcrowding of approximately $200 \%$. Modisadife described meal times at the prison as being "like opening the gates of hell when more than 4000 inmates - many of them hardened criminals - push and shove their way into the mess hall". ${ }^{19}$ The Sunday Independent described the cells in the Boksburg Prison as unhygienic and overcrowded to such an extent, that prisoners were forced to roll up their "[t]hin foam mattresses blackened by filth and grime" during the day, to create more space. ${ }^{20}$ One of the warders at the Boksburg Prison, Lawrence Baloyi, explained that warders at the prison were operating under considerable strain, since each warder was responsible for no fewer than 150 inmates. $^{21}$

2 November 1999 Cape Argus 3.

12 November 1999 The Daily News 3.

1912 December 1999 The Sunday Independent 6. The report went on to point out that, at this time, there was a staff shortage of 4495 members within the Department of Correctional Services.

2012 December 1999 The Sunday Independent 6.

21 lbid. 
The Minister of Correctional Services was greatly concerned by the seemingly intractable problem of prison overcrowding at this time. On 14 December 1999, he warned at a press conference of an approaching national disaster due to the continued increase in the numbers of prisoners within the system. Overall, South African prisons were 159\% overcrowded at the time. ${ }^{22}$ Prison overcrowding was, however, worse in some areas. For example, the Provincial Commissioner of Correctional Services for the Northern Province, Peter Ramashala, revealed that prisons in his province were $200 \%$ overcrowded. $^{23}$

The New Year did not herald much improvement in the problem of chronic overcrowding which bedevilled many of South Africa's prisons. The stresses and strains caused by this problem continued to generate heated public debate in the nation's press. In June 2000, for example, the Commissioner of Correctional Services for the Western Cape, Stephen Korabie, warned that prison overcrowding was so severe in his region that he might be forced to prohibit any new admissions to prisons in the province. Patricia de Lille, a member of parliament, threatened to apply for a High Court interdict prohibiting the referral of any further juvenile offenders to Cape Town's Pollsmoor Prison. ${ }^{24}$ Human Rights Commissioner, Jody Kollapen, warned that a constitutional obligation owed to prisoners was being breached, and described appalling conditions in certain of the holding cells for awaiting-trial prisoners at a Pretoria prison. No fewer than 60 prisoners were obliged to use a single toilet, which meant that: "In the event of an outbreak of diarrhea, some prisoners are forced to relieve themselves on a piece of paper and then throw it out of the window ....25 At this time, the South African penal system, which was designed for a maximum of 100384 inmates, was being forced to accommodate no fewer than 172271 prisoners; a massive 63970 of these were awaiting-trial prisoners. ${ }^{26}$

During July 2000, the problem of awaiting-trial prisoners received further attention in the media. The Minister of Correctional Services, Ben Skosana, visited Cape Town's Pollsmoor prison and commented negatively on the case of an 18-year-old awaiting-trial prisoner who had been forced to remain in prison for over eight months, since he could not afford to pay bail in the paltry amount of R100. According to the Cape Times, it had cost the State R18 480 to keep this prisoner locked up for this period. The newspaper commented that this particular inmate was only one of many awaiting-trial prisoners who had been accused of petty offences, and remained confined in Pollsmoor Prison because they were unable to pay bail amounts of less than R500. The newspaper also made the point - repeated decade after decade within South African penal discourse - that the longer a petty

\footnotetext{
15 December 1999 Pretoria News 2.

16 December 1999 Beeld 6.

The juvenile section of Pollsmoor Prison was $180 \%$ overcrowded, and the admissions centre 206\% overcrowded at the time. See 6 June 2000 Cape Argus 6.

2528 June 2000 Pretoria News 4.

268 June 2000 Sowetan 2.
} 
offender remained in prison, the greater the risk of that petty offender becoming a hardened criminal. ${ }^{27}$

In August 2000, public debate on the issue of prison overcrowding continued to generate alarm. The chairperson of the National Institute for Crime Prevention and Rehabilitation of Offenders, Carl Niehaus, warned that the penal system would collapse within a few years unless action was taken to remedy the problem of overcrowding. ${ }^{28}$ The Inspecting Judge of Prisons, Judge Hannes Fagan, commented during a human-rights conference at the University of the Western Cape that, due to overcrowding, conditions in South African prisons were "ghastly". Pointing to a massive three-fold increase in the number of awaiting-trial prisoners in South Africa over the preceding five years, Judge Fagan warned against the de facto development of a new form of "detention without trial", as periods of pre-trial imprisonment got longer and longer. ${ }^{29}$ Human Rights Commissioner, Jody Kollapen, also added his voice to the concerns being expressed at this time. He warned that chronic overcrowding in South African prisons amounted to a violation of the constitutional right to dignity of prisoners. He felt, however, that high levels of crime and violence in the country resulted in the muted response of the public to the crisis caused by overcrowding in South African prisons. ${ }^{30}$

In order to reduce the large numbers of awaiting trial prisoners, the National Council on Correctional Services recommended that all awaitingtrial prisoners who had been granted bail of less than R1000 be released. ${ }^{3}$ After their release, such prisoners would be required to report once a week to a police station near to where they lived. It could be assumed that these prisoners represented no threat to public safety and would not abscond or otherwise interfere with the administration of justice. It could also be assumed that the only reason that such prisoners remained incarcerated was because of poverty. It was calculated that the implementation of this proposal would lead to the release of about 13000 prisoners. Kollapen explained the economic sense of the proposal, as follows:

"It simply does not make sense to incarcerate someone at the cost of R90 a day (R630 a week or R2 700 a month) when that same person has been granted bail that does not exceed R1000 ... It is unacceptable to incarcerate people purely on account of their poverty. For the thousands who are unable to raise bail of between $\mathrm{R} 100$ and $\mathrm{R} 1000$, their incarceration is a direct result

276 July 2000 The Cape Times 3. The idea that South African prisons operate as de facto "universities of crime" has been expressed many times during South Africa's penal history. For eg, see Peté 2015 36(1) Obiter 17-40, particularly section 2 entitled "A Legacy of Hatred, Reduced Deterrence, the Creation of 'Universities of Crime' and Concern Over Global Perceptions".

282 August 2000 Beeld 2.

29 4-10 August 2000 Mail and Guardian 14. In paragraph 8.2 of his annual report for the year 2000 , the Inspecting Judge of Prisons stated that the number of awaiting-trial prisoners had almost tripled during the preceding five years, from 24265 in January 1995 to 63964 in April 2000 - an increase of $164 \%$.

3010 August 2000 Sowetan 12.

31 The National Council on Correctional Services was a statutory body set up to advise the Minister of Correctional Services. 
of their poverty and there can be no compelling reasons for their continued incarceration.

These pleas to release petty offenders, who were languishing in prison because they could not afford to pay small amounts of bail, were heeded. On 6 September 2000 a decision was taken by Cabinet to release awaitingtrial prisoners who had been granted bail which was R1000 or less. This was thought to involve approximately 11000 prisoners. ${ }^{33}$ It was also decided that a further 7000 prisoners would be granted early release on parole. Furthermore, the Department of Correctional Services sought to amend legislation requiring police to detain suspects charged with stealing goods worth more than R200. The proposed legislative amendment would allow police to release suspects immediately in cases of theft if the value of the goods alleged to have been stolen amounted to less than R2 $500 .{ }^{34}$

Although opposition parties generally supported the release of the 11000 awaiting-trial prisoners, a spokesman for the Democratic Alliance, Hendrik Schmidt, commented as follows:

"This so-called once-off decision by cabinet can mainly be attributed to the impending collapse of the justice system. Owing to poor management, disastrous financial policy, the backlog of cases in the judicial system, as well as the appointment of inexperienced staff, the average number of awaitingtrial prisoners has increased three-fold in our prisons over the past five years." 35

As was to be expected, the reaction of many members of the South African public to the release of large numbers of offenders, was hostile, to say the least. An example of such reaction may be found in the following extract from a letter to The Star by a certain C. McPherson of Sandton:

"Enough is enough. It may just be coincidence, but since the Government implemented its release of awaiting-trial prisoners, along with more violent, hardened criminals, the crime stories have been pouring in. Not 'friend of a friend of a friend' stories, but tales of crimes committed against people I know: armed robberies of business premises, burglaries at residential properties, hijackings, guns being stuck in people's faces and threats of death. It could be coincidence, but I doubt it. Either these crimes have been committed by people who have been released from prison, or by criminals who yet again have been sent the message that in South Africa we can get away with crime, we just can't get away from it!"

The public mood was not improved by the fact that the release of the awaiting-trial prisoners did not go as smoothly as planned. Around 160 prisoners, considered to be potentially "dangerous" - due to the serious nature of the offences with which they had been charged - were released in

\footnotetext{
10 August 2000 Sowetan 12.

7 September 2000 Sowetan 2.

9 September 2000 Independent on Saturday 1.

358 September 2000 Business Day 4. See also 9 September 2000 Independent on Saturday 1.

3622 September 2000 The Star 11.
} 
error. By 19 September 2000, the Minister of Correctional Services announced that only 19 of the approximately 160 dangerous prisoners released in error had been rearrested.

Despite the releases referred to above, the problem of chronic overcrowding in South African prisons continued to cause suffering and stress among all concerned. In November 2000, the Minister of Correctional Services was obliged to admit that that certain offenders were being confined in "appalling conditions", and that correctional services staff were being subjected to enormous stress in their work environment. These problems were directly related to overcrowding. The Minister admitted to suffering from sleepless nights due to the severity of the situation. ${ }^{38}$

During April of the following year, the head of the Judicial Inspectorate, Judge Johannes Fagan, described the conditions arising from overcrowding in the country's prisons as "horrendous". In his annual report to Parliament's Correctional Services Committee, the Judge pointed out that numerous prisons were grossly overcrowded, which led to horrendous conditions of detention, especially for awaiting-trial prisoners. He pointed out that many prisons were operating at $200 \%$ of their capacity, while one was operating at an astonishing $393 \%$ of its capacity. ${ }^{39} \mathrm{He}$ appealed to the Correctional Services Committee to enable more awaiting-trial prisoners to be released, and stated that these prisoners were being held under "inhumane conditions and in flagrant disregard of the Bill of Rights, the Correctional Services Act of 1998 and the United Nations Standard Minimum Rules for the treatment of Prisoners". ${ }^{40}$ Whereas in the past awaiting-trial prisoners used to spend at most two months in jail before their trials, the average was now 138 days. The Judge labelled this situation as "atrocious", and pleaded with the committee as follows:

"This is detention without trial as far as I'm concerned and I'm waiting for someone to take this to the Constitutional Court ... Please, we want your assistance. We've just got to have a provision that we can again release awaiting-trial prisoners".

An editorial in the Cape Times on 5 April 2001 commented as follows on Judge Fagan's report to the Correctional Services Committee:

"Judges tend to be temperate souls by nature, so the relevant authorities would be well advised to take note when Justice Johannes Fagan uses words like 'inhumane' 'atrocious' and 'horrendous' to describe the plight of awaiting-
trial prisoners".

An editorial in The Star warned that Judge Fagan's plea in favour of a qualified release for awaiting-trial prisoners would "spark howls of protest

\footnotetext{
20 September 2000 Die Burger 7; 20 September 2000 Cape Argus 5.

6 November 2000 Daily News 2.

See paragraph 8.1 of "Report of the Inspecting Judge of Prisons for the year 2000".

4 April 2001 Cape Times 3; and similar report in 4 April 2001 Eastern Province Herald 2.

Ibid.

52 April 2001 Cape Times 10.
} 
that the citizenry is not being protected against thieves and muggers", but concluded that:

"South Africans made a huge effort to create a constitutional dispensation that would put us among the civilized nations of the world. We dare not lose sight of that guiding light".

It was around this time that Israel Makoe - television actor and former prisoner - described life in a South African prison as follows:

"I saw people starved, watched friends being sodomized. You die inside. And you are made to beg and grovel for life's basics, feeling frightened and ashamed, beaten, mocked, hungry and bored".

During September 2001, the Minister of Correctional Services, Ben Skosana, announced in Parliament that a total of 168497 prisoners were confined in South African prisons on 31 July of that year. Of these, 117595 were sentenced and 50902 were awaiting trial. The prisons remained drastically overcrowded, since they were only designed to accommodate 105016 prisoners. The Minister made reference to the high crime rate, as well as the increasing numbers of awaiting-trial prisoners, and commented:

"The interventions we employed in 2000 to release low-risk awaiting-trial prisoners and advance the parole dates of certain categories, managed to reduce our prison population from 172000 to 160000 . However, the figure has once again risen to above $168000 "$.

The Minister announced that the Department of Correctional Services intended to dramatically increase the capacity of the prison system by 30 000 beds within a few years - by building low-cost "new-generation" prisons for medium- and low-risk prisoners. ${ }^{46}$

One of the dangers of prison overcrowding is that it poses a significant health risk to both prisoners and the general population. During October 2001, this danger was pointed out to the Parliamentary Portfolio Committee on Correctional Services by a certain Dr Stephen Craven, who had worked in the maximum-security section of Pollsmoor prison for 13 years. Among the potential health problems which he warned, could be caused by prison overcrowding, were dysentery, meningitis and tuberculosis. ${ }^{47}$

\footnotetext{
5 April 2001 Star.

14 March 2001 Sowetan 11.

19 September 2001 Natal Witness 1.

Ibid

3 October 2001 Die Burger 11. It is interesting to note that, a decade later, the same problem of chronic overcrowding in certain South African prisons continued to give rise to the same health concerns. A study published in the South African Medical Journal, in 2011, examined the probabilities of tuberculosis transmission among awaiting trial prisoners incarcerated in communal cells in Pollsmoor Prison near Cape Town. The authors of the study claimed that the conditions in which these prisoners were held, constituted a "health emergency", and pointed out that severe overcrowding played a major role in the very high risk of such prisoners contracting tuberculosis. In the words of the authors: "Levels of overcrowding $(230 \%)$ in communal cells and poor TB-case finding result in annual TBtransmission risks of $90 \%$ per annum. Implementing current national or international cell-
} 
During November 2001 it was reported that Parliament had approved the Judicial Matters Amendment Bill, which provided for the release of awaitingtrial prisoners who were unable to pay low amounts of bail. At that time it was estimated that there were 11250 prisoners who were confined in South African jails because they were unable to afford bail of R1000 or less. ${ }^{48}$

The various initiatives aimed at reducing the number of awaiting-trial prisoners confined in South African prisons started having some effect towards the end of 2001, when it was announced that the average number of such prisoners had fallen for the first time since $1995 .{ }^{49}$ The problem was, however, far from being solved. In March 2002, the Inspecting Judge of Prisons pointed out that more than two-thirds of the 55000 prisoners awaiting trial in South Africa would not be convicted. Upon release, many of these prisoners would have been unjustly incarcerated in overcrowded prisons for up to two years. ${ }^{50}$ The problem of overcrowding remained extremely serious in many of South Africa's prisons. For example, on 31 March 2002, a total of 178998 prisoners were confined in a penal system designed to accommodate only 109106 inmates, meaning that the system was $164 \%$ overcrowded. ${ }^{51}$ Adding to the concern expressed in the public discourse at this time, was that certain prisons were more seriously overcrowded than others, meaning that some prisons were more than $200 \%$ overcrowded. For example, in April 2002 it was reported in the press that the Pietermaritzburg New Prison, which had been designed to hold 1185 prisoners, was forced to accommodate 2984 inmates. Four communal cells, designed to hold 19 prisoners each, were crammed with 40 to 50 prisoners each. ${ }^{52}$ The Department of Correctional Services did not attempt to hide the fact that the constitutional rights of prisoners were being violated due to the chronic overcrowding. For example, in the Department of Correctional Services Annual Report for the period 1 April 2001 to 31 March 2002, the Commissioner of the Department, Mr Linda M. Mti, stated that one of the major obstacles faced by his department was "the extent of overcrowding in the prisons, which violates the human rights of inmates, undermines secure incarceration and undermines our efforts to create a rehabilitation-friendly environment." ${ }^{33}$

occupancy recommendations would reduce TB-transmission probabilities by $30 \%$ and $50 \%$, respectively". See Johnstone-Robertson, Lawn, Welte, Bekker and Wood "Tuberculosis in a South African Prison: A Transmission Modelling Analysis" 2011 101(11) South African Medical Journal 809-813. The duration of this problem over time provides evidence of its systemic, deeply-ingrained nature.

487 November 2001 Daily News 1.

49 According to the Department of Correctional Services Annual Report for the period 1 April 2001 to 31 March 2002, Part 3.1 "The Prison Population", the number of prisoners awaiting trial declined from 57676 on 28 February 2001 to 55285 in December 2001.

5025 March 2002 Pretoria News 15.

51 Department of Correctional Services, Annual Report for the period 1 April 2001 to 31 March 2002, Part 3.1 "The Prison Population".

5223 April 2002 Daily News 3.

53 Department of Correctional Services, Annual Report for the period 1 April 2001 to 31 March 2002, Introduction by the Commissioner of the Department of Correctional Services, Mr Mti. 
A year on from the honest but alarming statement of the Commissioner referred to above, the problem of prison overcrowding remained as intractable as ever. There was an increase in the daily average prison population from 172203 (during the period 1 April 2001 to 31 March 2002) to 181533 (during the period 1 April 2002 to 31 March 2003). ${ }^{54}$ This meant that South African prisons were $163.2 \%$ overcrowded during the 2002/2003 period - prompting the Minister of Correctional Services, in his annual report for this period, to refer to overcrowding as "one of the greatest challenges we continue to confront". ${ }^{55}$ The problems caused by prison overcrowding continued to be highlighted in the press. For example, in March 2003 it was reported that, according to a study conducted by the South African Law Society, "what prisoners particularly unsentenced- and awaiting-trial prisoners are experiencing comes well within the constitutional proscription of not to be treated in a cruel, inhuman or degrading way".

What is clear from the above, is that the problem of chronic prison overcrowding, as well as the manner in which it impacted negatively on the lives of thousands of prisoners - depriving them of certain basic human rights - was widely acknowledged during the period following South Africa's second democratic election. Discussion of the problem during the period in question formed a major part of public penal discourse, as reflected in the nation's press. Furthermore, the extent of the problem was accepted by various prison authorities in speeches and reports. As noted above, the specific driver of the crisis in prison overcrowding which came to a head at this time, was the extremely rapid rise in the number of awaiting-trial prisoners within South African prisons during the immediate post-apartheid period. Dirk van Zyl Smit - a leading South African penal scholar writing at the dawn of the new millennium, which falls within the period examined in this article - noted that the demise of apartheid had led to an overall decrease in the number of sentenced prisoners:

"The changes in the regime have had some surprising effects on the prison population. The official number of sentenced prisoners has increased only marginally from 90,485 on 30 June 1988 to 92,157 on 31 December 1998. This apparent increase in the sentenced prison population is misleading, however. The 1988 figures did not include sentenced prisoners held in the so-

54 Department of Correctional Services, Annual Report for the period 1 April 2002 to 31 March 2003, Part 2, "Strategic overview and key-policy developments".

55 Ibid - "Foreword by the Minister of Correctional Services Mr Skosana MP." It is interesting to note that, a full decade after this comment by the Minister of Correctional Services, the problem of prison overcrowding and a high prison population, remained a serious concern in South Africa. According to the Annual Report of the Judicial Inspectorate for Correctional Services for the period 1 Apr 2012 to 31 Mar 2013, South African prisons were approximately $128 \%$ overcrowded during that year. [See page 40 of the report, http://judicialinsp.dcs.gov.za/Annualreports/ANNUAL\%20REPORT\%202012\%20-\%202013. pdf (accessed 2015-02-04)]. In February 2013 the Minister of Correctional Services, Ndebele, commented as follows: "That our offender population has remained constant, whether you remove pass laws, group areas, or apartheid laws, should make us search more urgently for answers to the high prison population in South Africa." See Mail \& Guardian Online http://mg.co.za/article/2013-02-11-south-africa-has-highest-prisonpopulation-in-africa-says-ndebele (accessed 2013-02-12)].

5628 March 2003 Business Day. 
called independent homelands of Transkei, Ciskei, Venda and Bophuthatswana. A better, although still rough, way of understanding these figures is to calculate the rate of sentenced prisoners per 100,000 of the population in South Africa without the homelands on 30 June 1998 and then to compare it to the rate for the reunited South Africa on 31 December 1998. The respective rates for sentenced prisoners per 100,000 of the population show a dramatic decline, from 306 in 1988 to 216 in 1998".

The apparent decrease in the overall number of sentenced prisoners which may, perhaps, be regarded as a "democratic dividend" - was, unfortunately, more than offset by a dramatic increase in the number of awaiting-trial inmates in the newly democratic country:

"Although detention without trial and the imprisonment of civil debtors has been abolished, the number of unsentenced prisoners has increased from 19,418 on 30 June 1988 to 54,121 on 31 December $1998 \ldots$ This spectacular increase is a relatively recent tendency, as figures from a slightly different period show. While in the 20 years between mid-1976 and mid-1996 the number of unsentenced persons almost doubled (from 15,139 to 28,047), the numbers more than doubled in less than three years from 30 June 1996 to 31 March 1998, reaching 57,210 on the last date ...”

The period examined in this article thus marked a high point in the numbers of unsentenced prisoners clogging up South Africa's prisons. Following this period, a steady rise in the number of sentenced prisoners would contribute more and more to the problem of prison overcrowding. Writing in 2006, Giffard and Muntingh noted that:

"South Africa has a serious prison overcrowding problem. The total number of prisoners has grown steadily and dramatically over the last 11 years. The cause of the increase has changed during this time. Between 1995 and 2000, the major driver of the prison population rise was a massive increase in the size of the unsentenced prisoner population. After 2000, the number of unsentenced prisoners stabilised, and then began to decrease. But the prisoner population continued to grow, now as a result of an increase in the number of sentenced prisoners".

Fast forward a few more years to 2010 , and scholars were once again expressing concern at the high number of unsentenced prisoners in South African prisons:

"On 31 December 2010 the awaiting trial detainee population in South Africa was 46432 , approximately $30 \%$ of the total inmate population and almost double the Department of Correctional Services' proposed benchmark figure

57 Van Zyl Smit "National Report - South Africa" in Van Zyl Smit and Dünkel (eds) Imprisonment Today and Tomorrow: International Perspectives on Prisoners' Rights and Prison Conditions 2ed (2001) 589-608 589.

58 Van Zyl Smit in Van Zyl Smit and Dünkel (eds) Imprisonment Today and Tomorrow: International Perspectives on Prisoners' Rights and Prison Conditions 590. Van Zyl Smit noted the disastrous impact of chronic overcrowding on the basic human rights of South African prisoners, stating that: "the prisons are being flooded with unsentenced prisoners in such numbers that overcrowding is reaching a level where it is virtually impossible, even with the best intentions, to implement regimes that meet minimum standards of human dignity". See Van Zyl Smit in Van Zyl Smit and Dünkel (eds) Imprisonment Today and Tomorrow: International Perspectives on Prisoners' Rights and Prison Conditions 606. Giffard and Muntingh 2006 Open Society Foundation for South Africa. 
of 25 000. In some correctional facilities where overcrowding has reached a 'critical level', awaiting trial detainees account for $52 \%$ of the inmate population ... On 31 March 2010, 24305 remand detainees out of 50511

(48\%) had been in custody for longer than three months. Approximately $14 \%$

(3403) of these remand detainees had been detained for over 12 months, and

$3-4 \%$ (972) for over two years. Literally thousands of people in South Africa

spend long stretches of their lives in conditions frequently described as

'inhumane', and without access to educational or rehabilitative programs.

More than half of those in remand detention will be released due to acquittal

or their charges being withdrawn or struck off the roll".

Although the focus of concern during the post-apartheid period has "seesawed" between the numbers of sentenced and unsentenced prisoners confined within the South African penal system at any one time, one factor has remained constant - concern about the overall problem of prison overcrowding and its effects. South African prisons were to remain overcrowded throughout the post-apartheid period - although the degree of overcrowding fluctuated - from the first democratic election right up to the present date. The short period examined in this article sheds at least some light on this issue.

\section{THE IMPOSSIBILITY OF A "BUILDING SOLUTION" TO THE PROBLEM OF PRISON OVERCROWDING}

One of the ways in which the chronic overcrowding detailed in the previous section could be alleviated, although only to a limited extent, was by the construction of new prisons. It was reported that the Government, somewhat over-optimistically, planned to ensure that two new prisons were to be built every year over a period of 10 years. The extent of overcrowding was so great, however, that it was impossible for South Africa to "build its way" out of the problem. The Minister of Correctional Services, Mr Ben Skosana, was reported as admitting that South Africa could not solve the problem of overcrowding simply by building new prisons. ${ }^{61}$

One way in which the Government sought to relieve the considerable pressure it was under to increase prison accommodation, was to look to the free market. It was proposed that certain new prisons would be built and managed by the private sector. During July 1999, a contract worth R1.3 billion was concluded between the Government and a private consortium for the construction and management of the Mangaung Maximum Security Prison in Bloemfontein. During the same month, a further contract was concluded between the Government and a private consortium, South African Custodial Services, for the construction and management of the KutamaSinthumule Maximum Security Prison in Makhado (Louis Trichardt). ${ }^{62}$

60 Ballard "Research Report on Remand Detention in South Africa: An Overview of the Current Law and Proposals for Reform" 2011 Community Law Centre 5.

6116 December 1999 Beeld 6.

6228 July 1999 Beeld 5. In a speech delivered on 11 August 2000, the Minister of Public Works, Ms Sigcau, described South African Custodial Services as "a consortium equally owned by Wackenhut Corrections Corporation, a USA-based international prison-operating 
Together, these first two Public Private Partnership (PPP) prisons were to provide accommodation for 5952 prisoners. The Mangaung Maximum Security Prison had its first intake of prisoners on 1 July 2001, and the Kutama-Sinthumule Maximum Security Prison started operating on 20 February 2002. ${ }^{63}$ Unfortunately, the passage of time would show that privately-run prisons were not the "silver bullet" some may have been hoping for, for solving South Africa's problem of prison overcrowding. ${ }^{64}$

The Kutama-Sinthumule Maximum Security Prison, referred to above received publicity in the press due to its technologically-advanced facilities. ${ }^{65}$ According to a report in Beeld, the prison was designed to accommodate 3024 inmates, which would make it the world's biggest private prison, and it was to be reserved for the most serious offenders. All cells were controlled from a number of high-tech electronic-control rooms, fitted with one-way glass, which allowed warders to observe the prisoners. Each cell was connected to a control room by means of an intercom. Each section in the prison was equipped with its own gymnasium, and there was even an indoor soccer field. A number of classrooms were provided for the presentation of educational programmes. An American company, Wackenhut Corrections Corporation, was to be responsible for the rehabilitation of prisoners. Each prisoner would be evaluated upon entering the prison, taking into account the crime of which he/she had been convicted, as well as his/her educational standard, personality and psychological condition. Psychologists would then work out a rehabilitation programme for each inmate. The programme would determine into which section of the prison a particular inmate would be placed. Prisoners in different sections would wear different-coloured uniforms - blue, orange or green. Uneducated prisoners would be required to complete school grades 0 to 9 , while grades 10 to 12 were optional. Tertiary educational programmes

company and Kensani Corrections, a local empowerment company owned by a group of women".

63 Department of Correctional Services Annual Report for the period 1 April 2001 to 31 March 2002, Introduction by the Commissioner of the Department of Correctional Services, Mr Mti.

64 At the time of writing, the Mangaung and Kutama-Sinthumule Maximum Security Prisons remain the only two privately-run prisons in South Africa. Furthermore, considerable management problems have arisen in at least one of these prisons, Mangaung, forcing the Government to take over the running of that prison for 10 months between October 2013 and July 2014, before handing back control to G4S, the private-sector company contracted to run the prison. See "Correctional Services Withdraws from Mangaung Prison" 15 July 2014 City Press http://www.news24.com/Archives/City-Press/Correctional-services-with draws-from-Mangaung-prison-20150430 (accessed 2015-05-06). According to a 2013 report in Business Day "South Africa's two privately run prisons are a vastly expensive failure and are expected to cost the State about R20 bn over the 25 years of the contract ... Acting national Commissioner of Correctional Services, Jolingana, said the public-private partnerships had not been carefully thought through, and the Cabinet had decided not to proceed with four other private prisons. Mr Ndebele [the Minister of Correctional Services] added that the private prisons were an experiment that did not work. In the UK, where private prisons were pioneered, 'they are coming to a similar conclusion that they do not work very well". See Hartley "Ndebele Acknowledges Failure of Private Prisons", 6 November 2013 Business Day http://www.bdlive.co.za/ national/2013/11/06/ndebeleacknowledges-failure-of-private-prisons (accessed 2015-05-06).

65 The name of the prison was derived from the names of two former chiefs of the region. 
could be followed by correspondence. Rehabilitation programmes would range from classes for drug addicts and alcoholics, to classes dealing with child abuse and sexual problems. The prison was to be equipped with its own hospital, which had place for up to 50 patients. A medical doctor, a dentist and a radiologist would be on duty at the hospital permanently. Prisoners would never have to leave the prison premises, which would cut down on the possibility of escape. ${ }^{66}$

In addition to the private-sector projects mentioned above, the Government also proceeded with certain of its own construction projects during the period under review. Towards the end of 1999, plans were announced for the construction of a new super maximum-security prison in Kokstad in KwaZulu-Natal. The project was to attract a fair amount of controversy though. For example, the South African Council of Churches objected to the fact that inmates confined in this new facility would be subjected to solitary confinement:

"We protested vigorously in the apartheid years at the use of solitary confinement as an instrument of torture. We are angry that the present government appears to have adopted this means of torture as part of its plan to control crime. We do not expect that the members of the new government, many of whom suffered this particular torture in the past, can agree to its imposition in the new South Africa".

Fears were expressed that solitary confinement within the new super maximum-security prison would result in prisoners becoming insane. The Natal Witness described what life for inmates would be like as follows:

"Their days will be spent in solitude in a two-metre square cell with a small sink for water, a small concrete slab protruding from the wall as a table and another one filling a side for a bed. Prisoners will be allowed to the library and a short trip to the shower, one at a time. There has been some concern from local people that the nature of the confinement will make a lot of the prisoners go insane and will result in many suicides. Food will be cooked in a kitchen built outside the prison. Even trolleys delivering food to the cells will be selfpropelled. A trolley will drop food on electronically operated trays at the door of each cell and flaps will be simultaneously opened for a few seconds to allow prisoners to take their plates. There will be no chance to send messages or objects in and out of the prison by the kitchen staff ...."68.

Apart from concerns over the issue of solitary confinement, reservations were expressed in relation to the tender process for the project. The Democratic Party spokesperson for Correctional Services, Hendrik Schmidt, pointed out that the chairperson of the Parliamentary Portfolio Committee for Correctional Services, Aubrey Mokoena, was also the chairperson of the board of directors of a black-empowerment company called "Rainbow". Rainbow had entered into a joint-venture with Concor, a large multi-national construction company, for the completion of the R244.7 million Kokstad Prison project. Although the Parliamentary Portfolio Committee had no input on who should get tenders, the Democratic Party maintained that it was

6628 November 2001 Beeld 10.

671 October 1999 The Citizen 8.

6819 October 2000 Natal Witness 12. 
ethically and morally undesirable for Mr Mokoena to wear two hats. The South African Prisoners Organisation for Human Rights agreed that there was a clear conflict of interest between Mr Mokoena's positions. ${ }^{69}$

Even after it was built, the Kokstad Prison project continued to be dogged by controversy, and in September 2000 it was reported that the new prison, having cost R350 million, was standing empty because of a dispute between the Kokstad Council and the Government. The prison could not be opened until the town's water treatment and sewage works were upgraded, and the long-term bulk supply of water secured. This would cost R57 million. The Minister of Public Works, Stella Sigcau, visited the town and told the Town Council that it would have to bear this burden. The Mayor of Kokstad, Mandla Mate, complained that the amount was "too much for this little town to bear." Town councillors addressed a letter to President Thabo Mbeki in an effort to resolve the impasse. ${ }^{70}$ Finally, there was further controversy over the name to be given to the new prison. Zoleka Xapha, chairperson of Parliament's Correctional Services Portfolio Committee told City Press that "people in that area (that is, Kokstad) complain the prison was given their township's name, Ebongweni, when they were not consulted and their township is being associated with an institution that accommodates criminals, giving the impression they (the township people) are criminals". ${ }^{71}$

Despite the controversy surrounding the Ebongweni Maximum Prison in Kokstad, it was put into operation during the period 1 April 2002 to 31 March 2003 , with accommodation for 1440 offenders. ${ }^{72}$ In technological terms it was clearly a state-of-the-art facility. The Natal Witness described this aspect of the new prison as follows:

"Everything operates at the touch of a button. The solitary confinement cells and all the doors are closed and opened by someone in a control room where everything is viewed on screens ... Walking inside the prison is like walking through a network of veins. There is a system of passageways and iron gates and doors leading to different sections of the jail. You lose your sense of time and direction as you wind and turn in the passages .... Each section [of the prison] has its control room. The control room boasts a big table with a map outlining the layout of each section. It has hundreds of buttons and flickering lights ... The main control room could be likened to a radio station's editing room with its wall of monitors in colour and monochrome. With a click of a mouse, the whole jail can be locked or opened".

Apart from those prisons referred to above, other new prisons completed during the period under review, included the Qalakabusha Prison in Empangeni in KwaZulu-Natal, which was designed to accommodate 1392 prisoners, and the Devon Pre-Release Centre near Springs, which would accommodate 600 offenders. ${ }^{74}$ Clearly, however, the extent of overcrowding

1 October 1999 The Citizen 8.

27 September 2000 Eastern Province Herald 1.

15 October 2000 City Press 2.

Department of Correctional Services, Annual Report for the period 1 April 2002 to 31 March 2003, Part 2 Programme Performance, "Strategic overview and key policy developments".

7319 October 2000 Natal Witness 12.

74 See 6 November 2000Daily News 2; and 15 February 2001 Star 3. 
in South African prisons - as well as the exorbitant costs of constructing new prisons - meant that the prison authorities could not build their way out of the problem of chronic overcrowding.

\section{CONCLUSION}

Part One of this article has shown clearly that chronic overcrowding within South Africa's prisons remained a major problem during the period following South Africa's second democratic election. Discussion of the problem during the period in question formed a major part of public penal discourse, as reflected in reports appearing in the nation's press, as well as in the speeches and reports of various prison authorities. It is clear that all concerned were well aware of the manner in which chronic overcrowding impacted negatively on the lives of thousands of prisoners, depriving them of certain basic human rights.

As has been pointed out in the introduction to Part One of this article, an enduring theme which dominated South African public discourse during this time (as well as during the entire post-apartheid period) was fear of crime. The pressure on politicians to appear tough on crime was immense. In light of this it was, perhaps, inevitable that knowledge on the part of all concerned about the evils of prison overcrowding in South Africa would not translate into a solution to the problem. South Africans' fear of crime was simply too strong to allow for any measure which would have brought about a drastic reduction in the prison population.

There is, however, a further point to be made about the apparent "disconnect" between the public discourse which clearly recognized and condemned the problem of prison overcrowding on the one hand, and the continued failure of all concerned to implement true long-term solutions to the problem on the other hand. In his seminal work Discipline and Punish, the philosopher Michel Foucault pointed to the strange fact that imprisonment as a form of punishment was publicly and regularly condemned as an utter failure from the time it developed in Europe during the industrial revolution, but nevertheless grew from strength to strength. Foucault puts his finger on the cyclical and repetitive nature of critiques levelled at imprisonment as a form of punishment - stating that "the critique of the prison and its methods (which) appeared very early on ... was embodied in a number of formulations which, figures apart, are today repeated almost unchanged". ${ }^{75}$ The same appears true in relation to the problem of overcrowding in South African prisons, which is discussed over and over, from year to year and from decade to decade in the public media and in official reports, but is never truly solved. It could be, using an argument analogous to that used by Foucault to explain the persistent "failure" of imprisonment in Europe, that overcrowding is a systemic feature of this form of punishment as applied in South Africa. Persistent overcrowding in South African prisons may be linked to the fact that imprisonment in this country has always been used as a mechanism of

75 Foucault Discipline and Punish: The Birth of the Prison (1979) 265. 
social control, rather than simply a means of combating crime. ${ }^{76}$ Overcrowded prisons may be the inevitable consequence of efforts to keep order in a chronically-unequal society - in which millions live in appalling conditions below the poverty line.

Part Two of this article will examine and discuss the public penal discourse surrounding certain evils attendant on the massive overcrowding which afflicted the penal system in the years immediately following South Africa's second democratic election. These include poor conditions of detention; high levels of gang activity; the spread of HIV/AIDS; the escape of dangerous criminals from different prisons in the country; and instances of corruption and other criminal activity amongst prisoners and staff.

76 This was certainly true during the colonial, immediate post-colonial and apartheid periods. It has also been true during the post-apartheid period. Writing in the late 1990s, for eg, Van Zyl Smit pointed out that incarceration of prisoners during this period would continue "to play a prominent part in the South African system of social control". See Van Zyl Smit in Van Zyl Smit and Dünkel (eds) Imprisonment Today and Tomorrow: International Perspectives on Prisoners' Rights and Prison Conditions 591. 